\title{
ТЕРРОРИЗМ КАК ГЛОБАЛЬНАЯ УГРОЗА ХХІ В.: ТЕОРЕТИЧЕСКИЕ РАЗВИЛКИ ОСМЫСЛЕНИЯ
}

\author{
Магомедов Д. С.
}

В статье рассматриваются ключевые проблемы осмысления терроризма как международного явления. Становление транснационального терроризма автор связывает с серьезными изъянами формирующейся мирополитической системы, в которой доминируют США и их союзники, и кризисами государственных институтов в отдельных регионах.

Ключевые слова: терроризм, мировая политика, исламизм, национальное государство.

The article considers the key problems of understanding terrorism as an international phenomenon. The author associates the emergence of transnational terrorism with serious flaws in the emerging world-system, dominated by the US and its allies, and by crises of state institutions in certain regions.

Keywords: terrorism, world politics, Islamism, national state.

Проблема терроризма является одной из наиболее сложных в современных международных отношениях. Это напрямую связано с высокой актуальностью темы, а потому и ее политизацией. После событий 11 сентября 2001 г. угроза транснационального терроризма была выдвинута при активнейшем содействии США на передний план международной повестки дня, а объявленная «война против террора» активно использовалась администрацией Дж. У. Буша для укрепления позиций на международной арене. И если к началу 2010-х гг. казалось, что международный терроризм не представляет угрозы глобальному миропорядку, то резкое усиление радикальных исламистов из запрещенного в России ИГИЛ в 2014-2015 гг. изменило эти настроения. Подобное обстоятельство привело к эссенциализации терроризма в работах многих теоретиков и публицистов, приуменьшению его политической составляющей (борьба против мирового господства США, национально-освободительные мотивы, отстаивание политического и культурно-религиозного суверенитета) в пользу «мистических формулировок», поиску сущности терроризма в особой нетерпимости ислама или представителей исламских народов, объяснению через отсылку к иррациональной ненависти или же построению более сложной, но не менее абстрактной теории «исламского империализма», угрожающей западным ценностям [Ben-Dor 1996]. Подобные сугубо идеологические явления, направленные на легитимацию американской «войны против террора», стали предметом разоблачения [Ali Khan 2006], в 2006 г. был основан журнал под названием Critical Terrorist Studies, авторы которого поставили перед собой задачу критического пересмотра подобных представлений.

\footnotetext{
* Магомедов Даниял Сайгидгусейнович - соискатель кафедры политической теории МГИМО (У) МИД России. E-mail: danyalmm1985@gmail.com.
}

Век глобализации 4/2018 93-106

DOI: $10.30884 / v g l o b / 2018.04 .09$ 
В целом за последние 15 лет сформировалось целое междисциплинарное поле terrorism studies, в рамках которого особое внимание было уделено истокам и истории терроризма, роли несостоявшихся государств (failed states) в его распространении, проблемам финансирования террористических организаций, динамике террористических атак, а также успешности контртеррористических мер. Институциональный подход и теория игр в теоретическом плане определили своеобразие этого исследовательского направления [Sandler 2011]. В рамках данной статьи мы собираемся рассмотреть теоретические развилки, с которыми сталкиваются при осмыслении терроризма как мирополитического явления. Сосредоточенность на различных видах и проявлениях терроризма зачастую мешает поиску ответа на более базовый и однозначный вопрос, а именно: «Что такое терроризм в XXI веке?»

\section{Понятие терроризма: в поисках определения}

Сложность в определении данного явления можно увязать с рядом комплексов причин. Первый из них - исторический: на протяжении последних двух столетий под терроризмом понимали разные виды насилия [Tilly 2004: 8-9]. История появления термина в интеллектуальном дискурсе Европы восходит к эпохе Французской революции (1789-1799 гг.), когда он был тесно связан с массовым насилием сторонников революционных преобразований [Thackrah 2004; Lutz J., Lutz B. 2005: 19-27; Макуев 2007; Laqueur 2001: 5-10]. В XIX в. понятие терроризма было тесно связано с революцией, будучи методом слабых и незащищенных групп для достижения их целей. Как правило, террористические акты были направлены против представителей власти, а само понятие террора имело позитивные коннотации среди сторонников революции. В период Второй мировой войны семантическое поле понятия «терроризм» расширилось: теперь оно включало и массовые государственные репрессии против своих граждан, которые осуществляли в 1930-1940-е гг. власти Германии, Италии. После Второй мировой терроризм ассоциировался с революционными и национал-освободительными движениями в странах третьего мира. Как видно, во всех этих случаях речь идет о «разных терроризмах», разных социально-политических явлениях [Munson 2008: 78], что затрудняет поиск единой дефиниции: слишком узкое определение контрастировало бы с его широким употреблением в общественно-политической речи, в то время как расширение понятия делало бы его слишком размытым и с научной точки зрения бессмысленным.

Второй комплекс причин связан с проблемами аксиологического характера. Для правых и консерваторов терроризм предстает однозначно отрицательным явлением, в то время как для многих революционеров, наоборот, - оправданным средством достижения политических целей [Pearlstein 2004: 1-2]. И если в научном дискурсе еще можно выделить ценностно-нейтральное определение, то в рамках политической практики подобное представляется невозможным. На пути поиска единого определения терроризма, выработки общих юридических и организационных основ контртеррористического взаимодействия по большей части стоят политические разногласия и отсутствие политической воли [Stilles, Thayne 2006].

Ввиду стойких негативных коннотаций (по крайней мере, в глобальном политическом дискурсе) существует необходимость не допустить включения в число 
террористов «дружественных» политических движений. Это стимулирует активность именно политической борьбы как за определение терроризма, так и за его содержательное наполнение. Так, в годы холодной войны США считали допустимой поддержку различных правых террористических групп, равным образом как и СССР поддерживал различного рода левых террористов. На практике далеко не всегда легко отделить террористов от борцов национально-освободительного движения. Например, Организация Исламской конференции (ОИК) в 1999 г. специально подчеркнула, что к терроризму она не относит «народную борьбу, включая вооруженную борьбу против иностранной оккупации, агрессии, колониализма, гегемонии, нацеленную на освобождение и самоопределение в соответствии с принципами международного права» [Никитин 2009: 214]. На этом основании ОИК отказалась признавать Палестинское движение сопротивления в качестве террористического [Веселовский 2009: 29].

Подобные расхождения осложняют выработку единого юридического определения в рамках международного права. Как отмечено в Уставе Международного суда, «никакое международно-правовое определение преступлений терроризма странами-участницами согласовано быть не может» [Никитин 2009: 209]. А потому представляется оправданным операциональный подход, выдвинутый известным американским политологом Р. Кохэйном: терроризм как акт неправомерного насилия, определенный коалицией государств в качестве такового в рамках данной конкретной ситуации [Keohane 2002: 143]. Однако и здесь возникают сложности: в каждой из стран существуют собственные определения терроризма, что с юридической точки зрения ведет к разной классификации одних и тех же явлений (например, захват политика в заложники и его последующее убийство) как террористических или относящихся к организованной преступности. Это затрудняет как международное сотрудничество в борьбе с терроризмом, так и работу с национальными статистическими данными [см., например: Дремлюга 2014].

Попытки определить терроризм неразрывно связаны с историей международных усилий по борьбе с ним. Изначально речь шла о терроризме именно как о преступлении. В 1898 г. в Италии прошла первая международная конференция, посвященная терроризму. В 1926 г. состоялась Первая международная конференция по уголовному кодексу, на которой было принято решение о создании международной конвенции, направленной на борьбу с этим явлением [Веселовский 2009: 25]. В 1920-1930-е гг. этим вопросом занималась и Лига Наций, однако попытки воплотить в жизнь единую конвенцию по борьбе с этим явлением так и не удались [Акулов, Семейко 2003: 9]: Женевская конвенция о предупреждении терроризма и наказании за него (1937 г.) так и не была подписана [Galicki 2005: 744]. Впрочем, в ней была предложена первая формулировка понятия терроризма: «...все преступные действия, направленные против государства или рассчитанные на создание состояния террора в умах отдельных людей или групп людей или широкой публики» [цит. по: Соммье 2003: 59].

После Второй мировой войны на международном уровне впервые терроризм был упомянут только в Резолюции Генеральной Ассамблеи ООН от 18 декабря 1972 г. и увязывался с насилием против мирных граждан. Одновременно появляется около десятка различных международных правовых документов в разных отраслях международного сотрудничества, в которых звучало то или иное ситуативное (секторальное) определение терроризма. Например, речь шла о террориз- 
ме как о незаконном захвате самолетов (1971г.), захвате заложников (1979 г.), незаконном насилии, направленном против обеспечения безопасности на международных платформах на континентальных шельфах (1988 г.) и пр. [Galicki 2005].

Первое определение, которое претендовало на обозначение консенсуса, было озвучено Генассамблеей ООН в 1994 г. в резолюции «Меры по ликвидации международного терроризма», где под терроризмом понимались «преступные акты, направленные или рассчитанные на создание обстановки террора среди широкой общественности, группы лиц или конкретных лиц в политических целях», а также указывалось, что они «ни при каких обстоятельствах не могут быть оправданы, какими бы ни были соображения политического, философского, идеологического, расового, этнического, религиозного или любого другого характера, которые могут приводиться в их оправдание» [Документ... 1995].

Наличие определений, зафиксированных на международном уровне, не отменяет того факта, что каждое государство в политической и юридической практике стремится руководствоваться собственными трактовками. В США специально созданная комиссия по терроризму в 1986 г. предложила следующее определение: «Терроризм - незаконное применение силы или насилия против людей или имущества с тем, чтобы добиться политических или социальных целей угрозой правительству, населению или любым их сегментам» [Акулов, Семейко 2003: 5]. Схожим является определение, зафиксированное в американском законодательстве (параграф 2656f(d) в редакции 1997 г.): «...запланированное, политически мотивированное насилие, направленное против невоенных объектов и осуществленное субнациональными или неизвестными группами, как правило, ориентированное оказать влияние на определенную аудиторию» [Shughart 2006: 9]. Оно и было озвучено в политических заявлениях американских руководителей после событий 11 сентября (некоторые аналитики ошибочно указывали, будто оно было сформулировано после этих терактов) [Акулов, Семейко 2003: 6].

Полагаем, что наиболее продуктивным стал бы не поиск консенсусного определения «на все времена», а выделение сущностных черт терроризма, на основе которых в каждом конкретно-историческом периоде можно было бы конструировать подходящее определение. Среди таких черт мы предлагаем выделить следующие: представление о его политических целях, направленность на невоенных лиц (тем самым из состава терроризма исключаются партизанские действия в условиях войны), а также стремление посеять страх среди широких слоев населения или отдельных социальных групп. Более частные определения и типологизации будут результатом комбинации этих элементов. Отметим, что здесь мы близки к другим исследователям, пытавшимся пойти таким же путем. Так, исследуя различные официальные американские определения терроризма, политолог из США Р. Чакраворти отмечал, что все они построены вокруг трех ключевых концептов: «насилие», «запугивание» и «угроза мирным жителям» [Chakravorti 1994: 2340]. У. Шугарт выделял четыре ключевые составляющие современных определений терроризма: насилие в политических целях; спланированное действие; отсутствие связи с правилами ведения войны; нацеленность на психологический эффект [Shughart 2006: 10]. А К. Хармон выделял пять стратегий терроризма: создание социального хаоса, дискредитация конкретного правительства, нанесение экономического ущерба, подрыв национальной безопасности и распространение атмосферы страха для воздействия на международную среду [Harmon 2004]. 


\section{Причины терроризма}

Проблема определения терроризма тесно связана и с другим дискуссионным вопросом по поводу его истоков, а именно условий и причин, заставляющих различные политические группы прибегать к террору как методу достижения целей. Нужно подчеркнуть: понимая терроризм именно как метод, мы полагаем неактуальным подробно останавливаться на различных классификациях и типологизациях «терроризмов» [см., например: Lutz J., Lutz B. 2005: 11-13; Старцев 2016: 12-18], а считаем более рациональным остановиться на общих условиях, делающих возможным использование терроризма как политического метода, поведения. Уже затем можно будет перейти к рассмотрению конкретно-исторических причин обращения тех или иных политических вооруженных групп к террористическим методам.

В определении причин терроризма можно выделить два разных подхода. Первый (наиболее распространенный) представляет его как зависимую переменную, результат воздействия определенных условий, что лишает терроризм собственной субъектности (собственно, сама постановка вопроса о причинах обрекает исследователя на рассуждение в данной логике). Как правило, говорится о различных детерминантах: от социально-экономических факторов до обращения к психологическим чертам личности (религиозность, фанатизм) [Кудрявцев 2004: 90]. В психоанализе речь идет об инстинкте смерти, глубинных инстинктах, в которых заложено стремление к агрессии. Тем самым терроризм может быть оценен как выражение деструктивных и иррациональных психологических сил, некрофильской (в терминологии Э. Фромма) энергии, «любви к смерти», которая противопоставляется «любви к жизни» [Петухов 2010: 32-33].

Другой подход, скорее, намеренно стремится подчеркнуть субъектность терроризма, его рациональный характер. Весьма характерно, что все попытки детерминировать причины вступления людей в ряды террористов каким-либо одним фактором (половая, возрастная принадлежность, психологический склад, семейное, социальное или классовое происхождение, социальный статус, уровень образования, этничность) оказались неудачными [Shughart 2006: 11]. Так, исследования социального состава отдельных террористических групп отвергают предположение, будто терроризм является орудием бедных, поскольку среди исламистов оказалось немало выходцев из обеспеченных семей с хорошим образованием [Мирский 2005: 24].

А потому терроризм можно представить как рациональную модель поведения, определенный выбор, совершаемый группой лиц, предполагающей, что именно эта модель политического поведения принесет необходимый результат. Поскольку терроризм рассматривается именно как метод достижения политических целей, то в поле зрения попадают организованные политические структуры, а не деятельность отдельных социальных маргиналов [Munson 2008]. Использование теории игр внесло большой вклад в изучение таких вопросов, как переговоры с захватившими заложников, вербовка в террористы, контртеррористические меры, а также структура террористических сетей [Sandler 2011: 280].

Однако в каких социальных трансформациях последних 150 лет берет начало подобная рациональность, делающая терроризм возможным? Мы предлагаем вы- 
делить три ключевых условия, сделавших возможной успешность террористической активности:

1) технологические инновации: взрывные устройства становятся все проще воспроизводимыми в домашних условиях, а ввиду развития образования все большее количество людей обладают необходимыми знаниями и компетенциями для их изготовления;

2) демократизация политической жизни: если политический терроризм конца XIX - начала XX в. был направлен против представителей элиты, то в дальнейшем его объектами становились простые граждане. Акты устрашения могут быть эффективны только в том случае, если существуют институты влияния простых людей на власть, равным образом как и представители власти считают своим долгом в той или иной степени заботиться о безопасности граждан. Наиболее ярким примером успешности подобных террористических актов можно назвать осуществленные «Аль-Каидой» ${ }^{1}$ взрывы в Мадриде в 2004 г., накануне парламентских выборов. Эти нападения оказали влияние на избрание нового правительства социалистов, которое первым делом вывело испанские войска из Ирака [Хенкин 2007: 141-142];

3) медиатизация социальной и политической сферы: если знание об акте терроризма не станет достоянием широкой общественности, то он не произведет должного устрашающего эффекта; распространение ярких образов террористических атак способствует нагнетанию массовой истерии. Только со второй половины 1980-х гг. этот аспект был осознан и стал учитываться редакторами изданий при составлении материалов. Со средствами массовой информации связана проблема «демонстративного поведения», или же «заражения», когда, как писал известный политолог И. Александер, рассказ о террористическом акте, переданный через СМИ, может подтолкнуть неуравновешенного телезрителя к повторению этих действий самостоятельно [Alexander 1981];

Переходя к конкретно-историческим причинам роста терроризма в XX в., стоит указать на два ключевых процесса на мировой арене, начавшихся и происходивших в это столетие: деколонизация, явившаяся побочным результатом двух мировых войн, и глобализация, сопровождаемая вестернизацией незападных культур и ставящая под сомнение легитимность модели нации-государства [Kennett 2008; Harvey 2004; Dume 2009]. К началу XXI в. террористические организации стали самостоятельными негосударственными участниками международных отношений. Здесь стоит отметить, что взаимосвязь между внешней и внутренней политикой государств стала настолько тесной, что современные исследователи предпочитают говорить о мировой политике, подчеркивая особое качество политического взаимодействия в глобальном масштабе [Современные... 2012: 93]. Возникновение международного терроризма в последней трети XX в. явилось одним из факторов формирования подобной мирополитической среды. Отметим и тот факт, что в современном мире развитие исламского терроризма и усиление его роли в мировой политике в целом соответствует и общественному тренду по усилению незападных стран в определении глобальных процессов [Воскресенский 2014: 316].

\footnotetext{
${ }^{1}$ Деятельность данной террористической организации запрещена на территории Российской Федерации. - Прим. ред.
} 
Определение более конкретных причин появления терроризма также является дискуссионным. В зависимости от исходных теоретических установок терроризм может объясняться с позиции:

- борьбы за власть между великими державами; в условиях холодной войны речь может вестись о поддержке одной из сверхдержав террористических организаций на территории другой страны или же о возникновении терроризма в исламских странах как ответа на глобальное доминирование США (реалистская парадигма);

- неравенства экономического развития, превращения, в частности, африканских и азиатских стран в мировую периферию, «глобальный Юг», зависимый экономически (неоколониализм) от западных передовых экономик (неомарксистская парадигма). Необходимо заметить, что данную интерпретацию не стоит сводить сугубо к экономическому детерминизму, речь, как писал Г. И. Мирский, может вестись о реакции «на длительную эпоху унижения, гнева по отношению к тем, кто своим поведением до сих пор не позволяет мусульманам избавиться от незаслуженного комплекса неполноценности» [Мирский 2005: 24]. Тем самым экономические факторы тесно соседствуют с социально-психологическими;

- цивилизационных противоречий, борьбы различных точек зрения на мировое развитие в условиях политического и экономического доминирования стран Запада; здесь проблематика терроризма имеет ценностное измерение и тем самым оказывается связанной с более общим вопросом справедливости и неприятия той концепции справедливости, которая следует за глобализацией по неолиберальному образцу [Алексеева 2011: 21-22] (конструктивистская парадигма).

В отличие от террористов XIX в. современные их последователи угрожают не просто стабильности политического режима в отдельно взятой стране, но устройству мировой политики, ее государствоцентричности и доминированию западных держав, США в частности. Связь терроризма с эрозией института национального государства может просматриваться в различных аспектах. Одни исследователи полагают, что терроризм появляется в тех случаях, когда само государство прибегает к чрезвычайному насилию против отдельных групп населения и тем самым вынуждает их в условиях отсутствия возможности легально защищать свои интересы на ответные насильственные меры. Другие указывают на искусственность построения границ молодых - и еще не состоявшихся - национальных государств в процессе деколонизации, что привело к различным межэтническим противоречиям. Третьи связывают терроризм с антиэтатистской идеологией, что верно и для терроризма XIX в. (в основу которого положена идеология анархизма), и для исламского терроризма, основанного на исламской теологии: верховным суверенитетом обладает вовсе не государство, а умма, что, по замечанию А. А. Варфоломеева, «стирает межгосударственные границы и сводит на нет гражданственную самоидентификацию» [Варфоломеев 2011: 25]. Тем самым предлагаемая исламом социальная онтология оказывается несовместимой с социальной онтологией эпохи Просвещения, взятой на вооружение странами Запада в ходе колонизации мировых пространств. Как видим, во всех описанных выше случаях терроризм предстает как явление, направленное против существующего миропорядка.

Действительно, питательной средой для терроризма оказываются в том числе и так называемые несостоявшиеся государства (в них официальные институты власти не контролируют территорию и население), а также те страны, где суще- 
ствуют отдельные проблемные территории («икс-территории», по выражению официальных лиц Израиля). Именно там, где государственная власть прекращает действовать, терроризм получает свободу действий [Веселовский 2009: 60]. Однако было бы ошибочным делать вывод о прямой зависимости между развалом государственности и возникновением террористических групп. Как показала Б. Коггинс на основе анализа опыта 153 стран за 1999-2008 гг., ослабление государственности не ведет напрямую к появлению терроризма. Наиболее бедные государства, с низким уровнем социальной защищенности населения и слабыми государственными механизмами, такие как Буркина-Фасо, Нигер или Эритрея, вовсе не являются «террористически опасными». Таковыми будут те государства, где кризис официальных институтов сопровождается активизацией политического насилия [Coggins 2015]. Наиболее ярким примером является усиление ИГИЛ на территории Ирака, где после вывода американских войск так и не удалось построить эффективные государственные институты.

Во второй половине XX в. выделяются (с хронологической точки зрения несколько условно) три крупные волны терроризма на основе не только хронологии, но и ключевых идей и целей, преследуемых теми, кто использовал политическое насилие. Первая представлена «колониальным терроризмом», связанным с борьбой за независимость на пространствах колониальных империй. Подъем этой волны пришелся на первые десятилетия после окончания Второй мировой войны. Как правило, атакам подвергались символы колониального правления (военные базы, полицейские участки, резиденции местных властей). Успех оказался обеспечен тем, что относительно небольшие военизированные группы смогли деморализовать крупные империи, вынудив их пойти на широкие репрессивные меры, которые подтачивали их, империй, господство. Вторая волна терроризма (левый терроризм) пришлась на 1960-1970-е гг. и связана с деятельностью леворадикальных групп в Европе, США и Латинской Америке, требовавших более справедливого социального устройства. Общим для них стало использование леворадикальной риторики и идеологии, хотя в некоторых случаях (например, «Черные пантеры» или Симбионистская армия освобождения), пожалуй, только она и отличала эти группы от классических преступников. Стоит отметить, что именно тогда, в 1960-1970-е гг., терроризм превратился в подлинно международное явление за счет активного взаимодействия и сотрудничества европейских, азиатских радикалов и палестинских террористов [Shughart 2006: 24-25].

Третья волна терроризма, набравшая силу в конце XX в., представляет собой исламистский терроризм, а именно - множество различных террористических групп, объединенных политическим исламом, причем как суннитского, так и шиитского толка. Именно с исламистским терроризмом связан выход этого явления с внутринационального на международный и транснациональный уровни. Как подчеркивал К. Перлстейн, отличие международных (international) и транснациональных террористических организаций заключается в том, что первые получают поддержку национальных правительств, в то время как вторые действуют самостоятельно [Pearlstein 2004: 3]. Особенность этого вида терроризма заключается в том, что он является одновременно и политически, и социально, и религиозно мотивированным. Некоторые исследователи даже начали говорить о войне с терроризмом как о новой форме религиозной войны, противостоянии христианского и исламского мира, что, конечно, является идеологизированным тезисом, по- 
скольку собственно религиозные войны необходимо отличать от использования религии (радикальный ислам) для мобилизации широких групп поддержки [Косолапов 2006: 59; Пузырев 2008: 62-63]. А потому, проясняя разницу между понятиями «исламский» и «исламистский», отечественный востоковед Г. И. Мирский призывал использовать вторую форму, которая в меньшей степени увязывает метод террора с данной религией («исламистский терроризм», а не «исламский терроризм») [Мирский 2005: 23]. Исламистские террористы («Аль-Каида», «Исламское государство» ${ }^{2}$ ) выступили с проектом глобального мироустройства, став подлинным актором мировой политики и заставив другие государства пересмотреть собственное отношение к международной и национальной безопасности [Лебедева 2009: 75].

Эффективность исламистских террористических организаций заключалась в том числе и в том, что они имели транснациональный характер, намеренно выбирая сетецентричную форму организации в глобальном масштабе (множество ячеек, имеющих разные степени связи друг с другом, способные объединяться ради выполнения конкретных задач) [Bergesen, Lizardo 2004]. Так, значимую роль в поддержке «Аль-Каиды» играли ассоциированные группы - террористические организации в той или иной стране, преследующие скорее националистические цели, однако вступающие в тактический союз с исламистами [Лебедева 2013: 40].

Отечественный исследователь С. С. Веселовский следующим образом обозначил признаки транснационального терроризма: ключевые акторы - негосударственные, децентрализованные (то есть неиерархические) организации, наладившие между собой тесное сотрудничество и представляющие угрозу международному правопорядку, стремящиеся переустроить весь мир на традиционных началах. Для них терроризм - это не тактический, а стратегический инструмент борьбы. Террористические акты могут и преследовать широкие политические цели, и выступать инструментами давления на действующее правительство. Впрочем, как показали статистические исследования, наиболее эффективной подобная тактика является против авторитарных правителей (так как массовые теракты делегитимируют неудачную внешнюю или внутреннюю политику), нежели демократических [Park, Bali 2015].

Другая особенность современного транснационального терроризма заключается в его тесной связи с организованной преступностью, откуда террористы во многом и черпают финансовые ресурсы, необходимые для осуществления деятельности. А потому борьба с преступностью, коррупцией и терроризмом (все три явления ставятся в один ряд) некоторыми авторами рассматривается как первоочередная задача обеспечения национальной безопасности государства [Бородин 2007]. Отсюда исходит и чисто юридическое стремление толковать терроризм как уголовное преступление, проявляющее крайний нигилизм к нормам права. Так, юристы П. Г. Зверев и А. А. Клименко склонны рассматривать терроризм как политическое преступление, увязывая его как с преступлениями политиков, так и с попытками «теневой сферы» оказывать влияние на политическую систему [Зверев, Клименко 2008]. Взаимосвязь коррупции, организованной преступности и терроризма другими исследователями напрямую называется одной из ключевых

2 Деятельность данной террористической организации запрещена на территории Российской Федерации. -Прим. ред. 
проблем современной России [Кириллов, Ступина 2011]. Третьи склонны видеть более тесную связь между террористическими группами и преступностью, полагая терроризм «особым видом бизнеса», а потому борьба должна быть направлена против выгодополучателей [Частнов 2013]. Тем самым противостояние терроризму должно включать противодействие легализации доходов, полученных преступным путем, борьбу с продажей наркотиков и оружия.

Впрочем, вопрос о качестве связи между террористическими и преступными организациями является дискуссионным. По мнению бывшего заместителя министра иностранных дел России А. Е. Сафонова, особенность взаимосвязи терроризма и преступности в начале XXI в. заключается в их тесном переплетении: «Раньше они лишь иногда соприкасались, решали взаимовыгодные какие-то вопросы и затем расходились. Их контакты были не продолжительные и не широкие, локальные. Сегодня мы наблюдаем симбиоз» [Сафонов 2006: 14]. Однако не все исследователи согласны с данной точкой зрения. Например, Е. А. Степанова, исследовавшая взаимосвязь наркобизнеса и терроризма на примере Колумбии, Мьянмы и Афганистана, отмечала, что правильнее говорить не о слиянии, а о тесном взаимодействии между террористами и наркомафией (например, в Колумбии $60 \%$ доходов леворадикальной ФАРК и $70 \%$ доходов праворадикальной АУК формировались за счет продажи наркотиков), признавая, что «практически все военно-политические группировки, так или иначе вовлеченные в наркобизнес, в той или иной мере применяют террористические методы» [Степанова 2005: 200]. Более того, как подчеркивает К. Дааз, исторически грани между теневой или нелегальной экономикой, а также «легальным» и «нелегальным» политическим насилием подвижны и являются продуктом регулирующего воздействия государства. А потому объединять их вместе - значит вставать на позицию государства и доминирующего социального порядка, направленную на исключение всего, что оказывает ему сопротивление [Daas 2010].

В этой связи Л. Али Хан предлагал четко разделять деятельность международных преступных картелей, которая направлена в конечном счете на получение прибыли от незаконного предпринимательства, от собственно международного терроризма, порождаемого «треугольником насилия», сторонами которого являются подавляемое население (aggrieved population), репрессивный политический режим и те внешние политические структуры, которые оказывают содействие первой стороне в его борьбе. Такая аналитическая схема имеет свои достоинства для описания ситуации, например, в Палестине, Кашмире или Чечне, поскольку позволяет соотносить внешние и внутренние факторы, а также не упускать роль репрессивной государственной политики, однако ее недостатком является сведение проблемы терроризма к кризису национального государства [Ali Khan 2006].

В чем причины активизации международного терроризма в конце XX в. и его антиамериканской направленности? Среди первых причин необходимо выделить становление однополярного мира, где лидирующие позиции заняли США. Неудивительно, что именно Америка стала во всем мире восприниматься как олицетворение этого нового порядка, для многих представляемого несправедливым, а потому нелегитимным. Относительно низкий уровень жизни среди населения мусульманских стран стал базой для роста антиамериканских настроений и благодатной почвой для террористических групп. Этнические и конфессиональные различия лишь усиливали дистанцию и укрепляли образ врага, становясь допол- 
нительным аргументом для легитимации террористического насилия против США [Акулов, Семейко 2003]. Более глубокий политэкономический анализ показывает, что произошел симбиоз ислама как социально-экономической доктрины VIII в. и высоких технологий XXI в. Слишком тесное переплетение религиозных и социально-экономических императивов (не будем забывать, что изначально ислам возник как религия торговцев) сделало невозможной «исламскую реформацию» как движение к рационализации, которая бы помогла преобразить и социальный, и экономический, и культурный слой мусульманских обществ, что в условиях навязанной экономической глобализацией экономической гонки привело к их резкому отставанию и одновременно росту политико-религиозного радикализма (провал модернизации как рационализации сообщества привел к поиску ответов через уход в традицию) [Langman 2005].

Конечно, на наш взгляд, ни бедность, ни исламский фундаментализм, ни американизм являются не непосредственными причинами появления международного терроризма, а скорее благодатной почвой, базовыми условиями, которые позволили появиться международным террористическим группам в конкретноисторический период. Анализ зарождения тех или иных террористических организаций должен опираться одновременно на структурные и операционные факторы, или, другими словами, на общую динамику трансформаций и ситуативные процессы. Появление, например, «Аль-Каиды» стало результатом наложения определенных условий: крушения биполярной системы, активизации США на Ближнем Востоке, а также усиления доминирования западного мира в условиях глобализации [Azzam 2008; Gunaratna, Oreg 2010].

Таким образом, хотелось бы подчеркнуть, что мы рассматриваем терроризм прежде всего как метод действия военизированных групп, который включает в себя политические цели, нацеленность против некомбатантов, а также стремление посеять страх. Увеличение количества террористических групп и усиление их влияния мы увязываем с глобальными мирополитическими трансформациями, начавшимися во второй половине XX в. (прежде всего процессом глобализации) и связанными с трансформацией роли государства (и государственных институтов в частности) в мирополитическом взаимодействии. В значительной степени усиление терроризма указывает на кризис государствоцентричной системы, метод террора противостоит стремлению установить порядок на мировой арене. Сегодня мы наблюдаем складывание глобальной мирополитической системы, включая систему государственных мирополитических институтов. В этот процесс вовлечены (в той или иной степени) и официальные правительства исламских государств, что автоматически делает их частью общей системы (пусть и не на всегда справедливых и равных условиях). Однако проблема неравенства и несправедливости от этого не исчезает, хотя она не может быть решена в рамках классического межгосударственного взаимодействия (даже если под таковым понимать войны). Жесткость и относительно высокая эффективность системы заставляет недовольных искать иные пути борьбы, тем самым прибегая к непрямым, асимметричным стратегиям, включая террористические. А потому проблема современного транснационального терроризма не может быть редуцирована к деятельности небольшого числа радикалов, равным образом как и поиск методов борьбы с транснациональным терроризмом связан с двумя стратегиями: борьбы против конкретных террористических организаций и устранения общих условий их возникновения. 
В определенной степени терроризм является способом оспорить монополию государства на насилие, причем вне зависимости от преследуемых целей этот способ однозначно стоит определить как радикальный и политический, если под политикой понимать восходящее к Х. Арендт и К. Шмитту определенное действие, направленное на тотальное преобразование социальных отношений. Неудивительно, что ответ зачастую (и в США прежде всего) ищется в полицейских мерах, призванных лишить терроризм какого-либо собственно политического начала и обозначить его как преступление, либо поддающееся соответствующей юридической оценке, либо квалифицируемое как абсолютное зло. Отсюда проистекают и многочисленные заявления политиков по всему миру, что с террористами невозможно вести переговоры (тем не менее опыт разрешения конфликтов на Филиппинах и в Северной Ирландии показывает, что хотя включение в переговорный процесс легитимирует террористов, сам он ведет к избеганию насилия и разрешению конфликта) [Toros 2008]. Тот факт, что сегодня террористический метод ни в одном из случаев не привел к достижению политических целей, может говорить об успешности существующей политической системы по крайней мере с точки зрения нахождения тактических ответов на кризисные тенденции. Это позволяет купировать их, однако на системном уровне без преобразования существующей неолиберальной модели мирового развития они вряд ли смогут исчезнуть.

\section{Лuтература}

Акулов А. А., Семейко Л. С. Национальная безопасность США и международный терроризм. М. : ИСКРАН, 2003.

Алексеева Т. А. Возможна ли «глобальная справедливость»? // Вестник МГИМОУниверситета. 2011. № 6. С. 18-22.

Бородин П. П. Первоочередные аспекты стабилизации: борьба с преступностью, коррупцией и терроризмом // Социальная политика и социология. 2007. № 4. C. $103-115$.

Варфоломеев А. А. Терроризм как продукт антиэтатизма // Вопросы философии. 2011. № 6. С. 23-32.

Веселовский С. С. Многостороннее сотрудничество в борьбе с транснациональным терроризмом. М. : Навона, 2009.

Воскресенский А. Д. Мировые стратегии великих держав и логика объединения стран БРИКС // Китай на пути к возрождению: сб. ст. / отв. ред. С. Г. Лузянин. М., 2014. С. 314-328.

Документ OОН A/RES/49/60/ Меры по ликвидации международного терроризма. 17 февраля 1995 г.

Дремлюга Р. И. Криминологическая характеристика терроризма в Индонезии // Азиатско-Тихоокеанский регион: экономика, политика, право. 2014. № 1. С. 166-183.

Зверев П. Г., Клименко А. А. Особенности политического терроризма как элемента структуры политической преступности // Вестник Калининградского филиала Санкт-Петербургского университета МВД России. 2008. № 1-2. С. 18-22.

Кириллов И. А., Ступина С. А. Терроризм и коррупция: взаимосвязь и соотношение // Вестник Сибирского юридического института ФСКН России. 2011. № 1. C. $216-220$. 
Косолапов Н. А. Кризис рациональной всемирности // Международные процессы. 2006. Т. 4. № 10. С. 55-67.

Кудрявцев В. Н. Осмысляя терроризм. Предупреждение терроризма // Общественные науки и современность. 2004. № 2. С. 89-95.

Лебедева М. М. Мировая политика: тенденция развития // Полис. 2009. № 4. C. $72-83$.

Лебедева М. М. Акторы современной мировой политики: тренды развития // Вестник МГИМО-Университета. 2013. № 1. С. 38-42.

Макуев Р. Х. Терроризм в условиях глобализации // Государство и право. 2007. № 3. С. 43-49.

Мирский Г. И. Ислам и транснациональный терроризм // Политический класс. 2005. № 10. С. 23-29.

Никитин А. И. Конфликты, терроризм, миротворчество. М. : Навона, 2009.

Петухов В. Б. Информационный дискурс терроризма в контексте художественной рефлексии. М. : ЛКИ, 2010.

Пузырев Д. Терроризм в современных международных отношениях // Мировая экономика и международные отношения. 2008. № 8. С. 63-68.

Сафонов А. Е. Терроризм апокалипсиса // Международная жизнь. 2006. № 5. C. $12-17$.

Современные международные отношения / под ред. А. В. Торкунова, А. В. Мальгина. М., 2012.

Соммье И. Терроризм как тотальное насилие? // Международный журнал социальных наук. 2003. № 12. С. 48-61.

Старцев Г. В. Противодействие финансированию терроризма в системе обеспечения экономической безопасности России. М. : Перспектива, 2016.

Степанова Е. А. Роль наркобизнеса в политэкономии конфликтов и терроризма. М. : Весь Мир, 2005.

Хенкин С. М. Испанские консерваторы: траектория политической эволюции // Актуальные проблемы Европы. 2007. № 1. С. 128-152.

Частнов К. С. Некоторые аспекты правовых основ борьбы с терроризмом и экстремизмом и их финансированием // Вестник НГИЭИ. 2013. № 3. С. 169-174.

Alexander Y. The Media and Terrorism // Contemporary Terror: Studies in Sub-State Violence / Ed. by D. Carlton, C. Schaerf. London : Macmillan, 1981. Pp. 50-65.

Ali Khan L. A Theory of International Terrorism. Understanding Islamic Militancy. Leiden; Boston : Martinus Nijhoff Publishers, 2006.

Azzam M. Understanding Al Qa'eda // Political Studies Review. 2008. Vol. 6. No. 3. Pp. 340-354.

Ben-Dor G. The Uniqueness of Islamic Fundamentalism // Terrorism and Political Violence. 1996. Vol. 8. No. 2. Pp. 239-252.

Bergesen A., Lizardo O. International Terrorism and the World-System // Sociological Theory. 2004. Vol. 22. No. 1. March. Pp. 42-73.

Chakravorti R. Terrorism: Past, Present and Future // Economic and Political Weekly. 1994. Vol. 29. No. 36. Pp. 2340-2343. 
Coggins B. Does State Failure Cause Terrorism? An Empirical Analysis (1999-2008) // Journal of Conflict Resolution. 2015. Vol. 59. No. 3. Pp. 455-483.

Daas Ch. Terrorism and Organized Crime: One or Two Challenges? // Transnational Terrorism, Organized Crime and Peace-Building. New York : Palgrave Macmillan, 2010. Pp. 54-65.

Dume T. Liberalism, International Terrorism, and Democratic Wars // International Relations. 2009. Vol. 23. No. 1. Pp. 107-114.

Galicki Z. International Law and Terrorism // American Behavioral Scientist. 2005. Vol. 48. No. 6. Pp. 743-757.

Gunaratna R., Oreg A. Al Qaeda's Organizational Structure and its Evolution // Studies in Conflict \& Terrorism. 2010. Vol. 33. No. 12. Pp. 1043-1078.

Harmon C. Five Strategies of Terrorism // Dimensions of Terrorism / ed. by A. O' Day. Oxford, 2004. Pp. 123-143.

Harvey F. Globalized Terrorism and the Inevitability of American Unilateralism // International Journal: Canada's Journal of Global Policy Analysis. 2004. Vol. 59. No. 1. Pp. 27-57.

Kennett R. The Social Theory of Globalization and Terror // Journal of Policy Crisis Negotiation. 2008. Vol. 6. No. 2. Pp. 49-63.

Keohane R. Public Delegitimation of Terrorism and Coalition Politics // Worlds in Collision: Terror and the Future of Global Order / ed. by K. Booth, T. Dunne. New York : Palgrave Macmillan, 2002.

Langman L. The Dialectic of Unenlightenment: Toward a Critical Theory of Islamic Fundamentalism // Critical Sociology. 2005. Vol. 31. No. 1-2. Pp. 243-279.

Laqueur W. A History of Terrorism. New Brunnswick : Transaction, 2001.

Lutz J., Lutz B. Terrorism. Origins and Evolution. Basingstoke, Hampshire; New York : Palgrave Macmillan, 2005.

Munson Z. Terrorism // Context. 2008. Vol. 7. No. 4. Pp. 78-79.

Park J., Bali V. International Terrorism and the Political Survival of Leaders // Journal of Conflict Resolution. 2015. Pp. 1-28.

Pearlstein R. Fatal Future? Transnational Terrorism and the New Global Disorder. Austin : University of Texas Press, 2004.

Sandler T. New Frontiers of Terrorism Research // Journal of Peace Research. 2011. No. 48(3). Pp. 279-286.

Shughart W. An Analytical History of Terrorism, 1945-2000 // Public Choice. 2006. Vol. 128. No. 1/2. Pp. 7-39.

Stilles K. Thayne A. Compliance with International Law. International Law on Terrorism at the United Nations // Cooperation and Conflict: Journal of the Nordic International Studies Association. 2006. Vol. 41(2). Pp. 153-176.

Thackrah J. Dictionary of Terrorism. London; New York : Routledge, 2004.

Tilly Ch. Terror, Terrorism, Terrorists // Sociological Theory. 2004. Vol. 22. No. 1. Pp. 5-13.

Toros H. "We don't Negotiate with Terrorists!": Legitimacy and Complexity in Terrorist Conflicts // Security Dialog. 2008. Vol. 39. No. 4. Pp. 407-426. 